\title{
Powers and process in revenue law
}

\author{
by Bernard Robertson
}

$\mathrm{W}$

hy are tax authorities given powers of intrusion and enforcement that would be unacceptable in any other area of law enforcement? And why do we hear argument about ideas like a General AntiAvoidance Rule that clearly breach fundamental requirements of the rule of law?

We cannot understand these questions without going back to some basic consideration of substantive tax law, because that is where the problems start.

A substantial part of the revenue of all developed countries is raised from labour or income taxation. The wisdom of taxing people for setting out to earn a living is a matter that might be discussed if we were today designing a tax system from scratch, but income tax appears to be here to stay. Unfortunately, over the last century a sharply increased proportion of the workforce have become employees. Employees are sheltered from the inequities and inefficiencies of income tax; public servants and academics are employees and most lawyers and accountants are paid essentially as employees. It is therefore very hard to get any sensible discussion of these issues.

The root of the problem is that there is no such thing as income. It is an intellectual construct.

\section{DEFINITION OF INCOME}

The classic economic definition of income is net change in wealth plus consumption over the period. But this is certainly not what is taxed. For a start there is no capital gains tax in New Zealand; in the UK it is charged on a realisation basis and not on an accrual basis, and significant assets, such as family homes, may be exempted. Even this definition assumes a distinction between consumption and investment expenditure, but as every self-employed person and small business knows there is no such clear distinction.

Dictionaries frequently equate income with receipts, but again, that is clearly not what is taxed. Part of the problem, perhaps, is that employees do tend to equate income with receipts, but they are aware neither of the arbitrary decisions taken between the receipt from the customer and their pay packets, nor of the extent to which their fringe benefits are taxable.
Unfortunately, employees have a seriously distorted view of remuneration and they dominate political and professional debate on these issues. There are two main problems. The first is that, as mentioned above, selfemployed people have to make a number of decisions about how much of their receipts to plough back into the business, how much to spend on business equipment, offices, business travel which has personal benefits, car etc. In the case of employees these decisions are taken by other people and do not directly affect each month's pay packet. Employees are therefore largely unaware of the arbitrary nature of many of these decisions and of the difficulty in distinguishing between personal and business use of computers, cars, social life etc. When they see selfemployed people making these necessarily arbitrary decisions, therefore, they accused them of tax rip-offs.

But if, for example, academics were to suffer cuts to conference or sabbatical travel allowances, they would see their terms of service as having got worse even though they would regard these matters as business expenses rather than taxable remuneration. So, employees too receive non-taxable benefits, which are part of the attractions of the job and therefore part of the reward derived from doing that job.

Secondly, many employees are unaware of the true level of their taxable remuneration even as technically defined. The rules relating to superannuating are extremely complicated, but there are other examples. To take a trite example, if an employer provides free parking in the building owned by the employer this is not taxable, but if the employer pays a neighbouring multi-story car park to provide parking, this is a taxable benefit. Economically, of course, this distinction makes no sense, but the important point is that few of the employees concerned are even aware of whether their car parks are taxed.

The end result is that employees have a completely false sense that there is some self-defining concept of income. As we have seen, there is not. But this misperception leads to some important consequences.

The first is that some senior judges today apparently do not understand a concept clearly understood by common law judges in previous generations today. Since there is no such thing as income, the only thing that can be taxed 
under the Income Tax Acts is that which is defined as income under the Acts. Yet today we find paragraphs in judgments, which the above discussion shows to be plainly fallacious such as:

\section{'The objective of the Income Tax Act is to collect tax on income. Income is derived from the substance of a transaction, not its form. It is therefore necessary to have regard to the substance of a transaction and not just the form in which it is fabricated to determine the true income and the tax which is payable on that income. For either the tax authorities or the Courts to do otherwise is to thwart the objective of the Act'. (per Thomas J in BNZI Investments v Commissioner of Inland Revenue [2001] 3 NZLR XXX para [102].}

We can now see that although this paragraph expresses sentiments with which many employees, and hence policy makers, would agree, it is wrong at every step. The first sentence is wrong as there is no such thing as income and it cannot therefore be the objective of the Act to raise income on it. The sentence should read: 'the objective of the Income Tax Act is to collect tax. For this purpose, it defines a concept known as income'. The next sentence is wrong because it hinges around a non-existent idea, the 'true income' derived from a transaction. As we have seen there can be no such thing as the true income from a transaction any more than we could define a 'true profit', profit being measured simply by arbitrary accounting rules.

Tax enforcers, all employees, are therefore engaged in trying to identify and measure something, which they believe exists, but which does not: 'true income'. This can no more be pinned down than can a moonbeam, but the enforcers do not understand the fundamental reasons for this and become more and more frustrated and inclined to blame the problems they meet on the dishonesty of the taxpayers. The solution, in their minds, is ever increasing powers of intrusion, unilateral assessment etc.

The next challenge is that the process becomes interactive. Since only what is defined in the Act as taxable is taxable, people will always strive to achieve effects they wish to achieve in a way that minimises their tax liability. As taxpayers find new ways of acting just outside the boundary of what is taxable, so the government changes the definition of what is taxable to account for the new challenge. This is why there are so many Income Tax Amendment Acts each year and why tax law becomes so complicated. This argument is considered at length by Professor John Prebble in his papers 'Philosophical and design problems that arise from the ectopic nature of income tax law and their impact on the taxation of international trade and investment' (1995) 13 Chinese Yearbook of International Law and Affairs 111-139 and 'Ectopia, formalism, and anti-avoidance rules in income tax law' in Krawietz MacCormick \& von Wright (eds)
Prescriptive Formality and Normative Rationality in Modern Legal Systems, Festschrift for Robert S Summers Duncker and Humblot, Berlin, (1994) 367-383.

Tax avoidance is thus an inherent aspect of taxing an intellectual construct, which has no independent existence outside tax law. Where what is taxed is something real with an independent existence, such as alcohol or tobacco, we do not regard changing our behaviour so as to reduce the amount of tax we pay as tax avoidance. The consequences of the inherent nature of income tax avoidance are predictable. First, the enforcers demand wider and more intrusive powers, believing that increased knowledge will enable them to deal with the challenges more effectively. Next, they take the power to make unilateral assessments and reverse the burden of proof so that the taxpayer has to prove that its income is not what the Revenue says they think it is. Finally, they bring in the ultimate weapon, the general anti-avoidance rule. This is equivalent to the abandonment of clear definitions of offences in criminal law or to giving the police the power to disallow any 'clever legal defence'.

All these moves are based on the fallacious assumption that there is some true income that each taxpayer receives and on which they should pay tax. This is essentially an employee's concept, but, as we have noted, not only are the experts nearly all employees but also the politicians are driven by the bulk of voters who are either employees or beneficiaries.

The same problem arises with the distinction between capital and income, especially since the capital value of something may well represent an assessment of its income earning potential, together with time preference and risk elements - the same ingredients that determine the interest rate for a loan.

In McGuckian, the taxpayers owned a company from which they drew no dividend for years. They then assessed the dividend they were entitled to and sold the right to it to a lawyer for 99 per cent of the assessed value. Had they paid themselves the accrued dividend it would have been taxable income. But the payment the lawyer made to them was, they argued, a one-off capital payment and hence untaxable.

Now, there could be genuine reasons for entering into such a transaction. If I own shares in a company in Russia, for example, I might sell the right to receive the dividends for the next year or two to someone else, perhaps a bank in Russia. The payment I receive would be a capital payment. But the discount I would accept would be determined not only by the risk factor but also by the fact that the payment I had received would not be taxed as income. And, of course, if I sell the shares themselves the price I receive will be based on the income I will be foregoing, yet the price is classed as a capital payment, unless I am a dealer in shares. 
In McGuckian, however, the transaction appeared to serve no business purpose and was doubtless made simply with the intention of pushing the receipt outside the definition of 'income'. The House of Lords had little difficulty in characterising it in that way and holding that the payment therefore represented income in the hands of the taxpayer.

But Lords Steyn and Cooke went further. They took a 'broad' approach to statutory interpretation, talking about the 'spirit' of the Act and interpretations which would achieve parliament's 'intention'. Thomas J took the same sort of line in BNZI when he said at para [61]:

'For this purpose, the Court is required to examine the text in the light of its purpose, the scheme of the Act and, as far as it can be gleaned, the legislative policy. The resulting answers can be said to represent Parliament's intent'.

This approach is revealing. It reveals that the judges do not consider that any fundamental rights are in issue. Many of the same lawyers who in the context of criminal law and procedure will vigorously defend the requirement for strict legal definitions and for strict limits on police powers appear to see no conflict in adopting a completely different approach to tax.

This raises the question of a fundamental right to retain one's property unless deprived of it by process of law. Article 1 of Protocol 1 to the European Convention on Human Rights provides that the right to property does not prevent governments raising taxes. But we know that a right to property does not stop all sorts of government takings, such as expropriation to deal with 'hold-out' problems in road and rail construction projects. But all such takings should be in accordance with law and so should taxation.

The Petition of Grievances 1610 referred to the 'indubitable right of the people of this kingdom not to be made subject to any punishment that shall extend to their lives, lands, bodies or goods other than such as are ordained by the common law of this land or by their common consent in Parliament.' Dicey made one of the three pillars of the rule of law the principle that no one was to be made to suffer in body or goods save for a distinct breach of the law.

One might have thought that there was no right more fundamental, and more important to more people, than that one should not be deprived of the fruits of one's labours except by law. But for some reason this proposition is completely forgotten by lawyers when we are dealing with tax. We get so far as to have judicial statements such as Thomas J's para [93] in BNZI, which he says:
'No provision (or judicial doctrine) can ever enable taxpayers to predict with absolute certainty that a proposed

arrangement will or will not constitute tax avoidance . . . at the margin, no bright line can be drawn between a valid commercial scheme and tax avoidance, and it has become unproductive to hanker after a level of precision and certainty which can never be realised'.

If such a pronouncement were to be made about crime there would be outrage and rightly so.

There are in fact two practical solutions to this problem, which do not involve the step of abolishing income tax altogether. The first is to recognise that these problems get worse when we have graduated rates of tax, which encourage income splitting and other forms of evasion, and when we have exemptions and allowances, which encourage re-characterisation of income or changes in behaviour simply to avoid tax. If we opt for a relatively flat, broad tax scale in which a single relatively low rate applies to most people with no exemptions or tax breaks, the problem of tax avoidance is substantially reduced.

The second solution is to reconsider where tax investigative effort is directed. The focus on large businesses is misplaced, since corporation taxes are essentially withholding taxes. As long as we have income tax it is necessary to have corporation taxes at approximately the same rates to prevent tax driven retention of earnings, but tax evasion by corporations is not in the long term important, since it leads to higher profits, which lead ultimately to higher taxes for shareholders.

The evidence is that tax avoidance by large corporations and a small number of very rich individuals are heavily outweighed by widespread failures to report income at the small business end of the scale. Here the problems are straightforward concealment and fraud. No unusual legal powers or extended definitions are required to deal with this, just straightforward investigative effort.

Consideration of the powers and processes of the Inland Revenue therefore cannot be divorced from the substantive law of tax and from tax design issues such as progressivism, marginal tax rates and comprehensiveness. Unless these matters are dealt with, any attempt to defend the procedural rights of taxpayers will be open to the challenge that it threatens to allow dishonesty to flourish and this challenge will be hard to deal with.

Bernard Robertson

The author is editor of The New Zealand Law Journal 